\title{
Wind Energy Resource Assessment in South Western of Algeria
}

\author{
Asma Abderrahim*, Nassera Ghellai, Zakaria Bouzid, Younes Menni \\ Unit of Research on Materials and Renewable Energies, Department of Physics, Faculty of Sciences, Abou Bekr Belkaid \\ University, P.O. Box 119-13000-Tlemcen, Algeria
}

Corresponding Author Email: abder.asmaa@gmail.com

https://doi.org/10.18280/mmep.060201

Received: 29 April 2019

Accepted: 4 June 2019

\section{Keywords:}

wind energy, wind resource, assessment wind potential, Weibull parameters, the southwest of Algeria

\begin{abstract}
The aim of this paper is to evaluate the wind potential in southwestern Algeria, according to months, seasons and entire years and contribute to the updating of the wind map in Algeria at $10 \mathrm{~m}$ from the ground, using hourly data for wind collected over a period of more than 30 years. The wind data analysis was done using the Weibull function at $10 \mathrm{~m}$ from the ground. Then we did the statistical analysis, which includes several fundamental properties, such as Weibull parameters, mean wind speed and average power density. The results give the city of Tindouf as the one with the highest annual average speed with 5.39 $\mathrm{m} / \mathrm{s}$ at $10 \mathrm{~m}$ from the ground. As for the temporal study, it gives that spring is the best windy period.
\end{abstract}

\section{INTRODUCTION}

An unprecedented boom, especially after the 1973 oil crisis that alerted states producing fossil energy [1]. In fact, after the year 2000, the fluctuating context of fossil fuels, the explosion of worldwide demand for electricity and environmental awareness have drawn attention to the need for clean and sustainable energy.

Electricity generation in North Africa using renewable energy resources has recently gained momentum through several projects such as the Desertec Industrial Initiative, where bulk wind, CSP and PV large scale export is the most feasible option [2].

North African countries with high levels of direct solar radiation, the goal of these plans is to create a new renewable energy generation capacity, using solar and wind energy on the basin Mediterranean [3].

In Algeria, the objectives fixed by the company to capital action NEAL (Novel Energy Algeria), centered on the increase of the renewable power production in $1400 \mathrm{MW}$ in 2030 and $7500 \mathrm{MW}$ at the beginning of 2050. The electrical energy will result from solar power plants, exclusively solar, or from hybrid solar power plants, which also use other renewable or conventional forms of energy, rather natural gas [4]. Recently, Boudghene Stambouli concluded that there is a considerable potential in Algeria for the renewable use of a source of energy [5], in particular as regards solar and wind energy producing fewer greenhouse gas emissions [6].

In the field of the evaluation of the wind potential, the scientific literature proposes recent studies on different areas of the globe; among them: the study of wind resource assessment offshore the Atlantic Iberian coast with the WRF model in Spain [7]; Use of spatio-temporal calibrated wind shear model to improve accuracy of wind resource assessment in the USA [8]; 3D statistical mapping of Germany 's wind resource using WSWS [9]; Wind resource assessment and economics of electric generation at four locations in Sinai Peninsula, Egypt [10]; Multi criteria decision analysis for offshore wind energy potential in Egypt [11]; Wind energy characteristics and wind park installation in Shark El-Ouinat, Egypt [12]; Offshore wind resource assessment and wind power plant optimization in the Gulf of Thailand [13]; Offshore wind resource assessment of Persian Gulf using uncertainty analysis and GIS [14]; Wind resource assessment using SODAR and meteorological mast - A case study of Pakistan [15]; Wind resource potential assessment using a long term tower measurement approach: A case study of Beijing in China [16]; Validation of wind resource in 14 locations of Nepal [17]; Statistical learning approach for wind resource assessment in United Kingdom [18]; Wind resource assessment of Northern Cyprus in Turkey [19]; A new methodology for urban wind resource assessment in Portugal [20] et. The wind resource assessment around coastal areas of the Korean peninsula [21-22].

Numerous works indicated that Algeria was characterized by the most important wind potential; in particular, the first approach is the establishment of Atlas and wind map in Algeria. In this context, we can quote the contribution to the updating of the card of the wind of Algeria, adding the study of Hassi R'mel South of the country to the Atlas of the wind by Challali and al [23], few studies were led to estimate the wind resources, although the publication of the Atlas of wind by Kasbadji [24-25] gave rise to a growth of the domain of the evaluation of the wind. The second approach is the assessment of wind potential and the design of wind energy conversion systems. In this context, we can mention the studies by Himri et al. [26-31] who were among the first to give a statistical analysis of the wind speed in different regions of Algeria and the work on the evaluation of wind resources at different sites in Algeria (Boudia et al. [32-37], Benmedjahed et al. [38-39], Bouzid et al. [40], Diaf et al. [41], Aksas et al. [42]).

In this study, we suggest making an analysis of the wind resource in the Southwest region of Algeria by choosing two 
sites. Furthermore, the objective of this work is the contribution to the updating of the wind Atlas of Algeria in $10 \mathrm{~m}$ of the ground by using meteorological data according to the wind speed adjusted by the distribution of Weibull. So, the estimation of the average speed and the average density of power, according to the months, seasons and of the year.

\section{SITES SELECTIONS AND WEATHER DATA}

\subsection{Sites presentation}

Bechar is the largest city in southwestern Algeria, located $852 \mathrm{~km}$ northeast of Tindouf which is located at the extreme southwestern tip of Algeria. The geographic location of the two weather stations is shown in Figure 1.

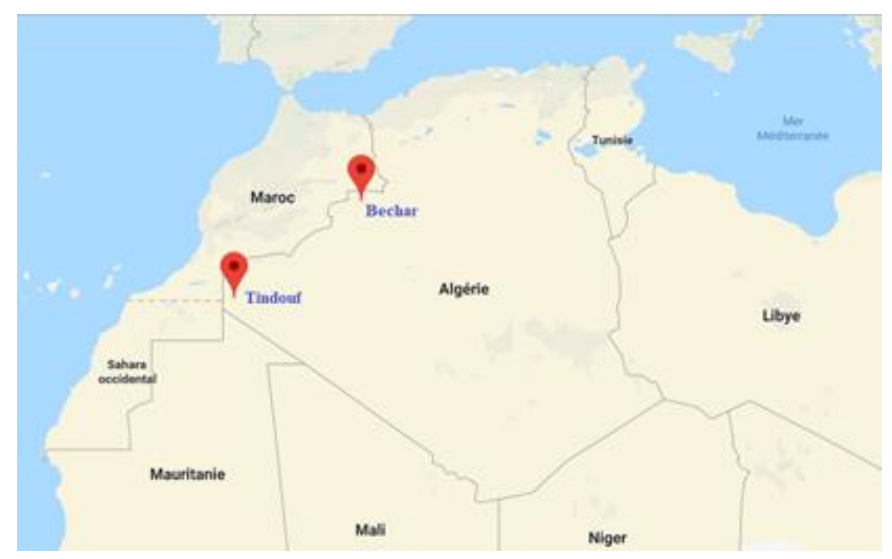

Figure 1. The geographic location of the wind measurement station in Algerian map

\subsection{Data analysis of wind speeds}

In this article, the geographic coordinates of weather stations and years of measurements are presented in Table 1.

Table 1. Geographical coordinates of the data collection station used in the study

\begin{tabular}{cccccc}
\hline Stations & $\begin{array}{c}\text { Station } \\
\text { code } \\
(\text { AWS })\end{array}$ & $\begin{array}{c}\text { Longitude } \\
\left({ }^{\circ}\right)\end{array}$ & $\begin{array}{c}\text { Latitude } \\
\left({ }^{\circ}\right)\end{array}$ & $\begin{array}{c}\text { Altitude } \\
(\mathrm{m})\end{array}$ & $\begin{array}{c}\text { Measurement } \\
\text { Period }\end{array}$ \\
\hline Bechar & 605710 & $-2,27$ & 31.646 & 811.1 & $01 / 01 / 1988$ \\
& & & & & $31 / 12 / 2017$ \\
\hline Tindouf & 606560 & $-8,167$ & 27.7 & 442.9 & $01 / 01 / 1987$ \\
& & & & & $31 / 12 / 2017$ \\
\hline
\end{tabular}

We used wind speeds at 10 meters above ground level recorded every hour. These data were obtained via "NCDC Climate Data Online" [43].

\section{WIND ANALYSIS MODEL}

\subsection{Weibull statistics of wind speed}

To estimate the potential of wind energy of any site, it is important to characterize the probability distribution of the wind speed of the site. The distribution of Weibull is the most wide-spread to adjust the distributions of the wind speed for a period of time [44-45]. He is defined by the following equation:
$f(v)=\left(\frac{K}{A}\right)\left(\frac{v}{A}\right)^{K-1} e^{-\left(\frac{v}{A}\right)^{K}}$

where $\mathrm{f}(v)$ is the probability to observe the wind speed, $v$ is the wind speed $(\mathrm{m} / \mathrm{s}), K$ is the parameter of shape of Weibull (dimensionless), and $A$ is the parameter of scale of Weibull $(\mathrm{m} / \mathrm{s})$.

There are different methods for estimating parameters of the Weibull distribution [46-47]. In this work, for the analysis of the wind data, the maximum likelihood method was used, taking into account its good performance [48]. The parameters of Weibull $K$ and $A$ can be estimated by the following equations:

$K=\left[\frac{\sum_{i=1}^{n} v_{i}^{k} \ln v_{i}}{\sum_{i=1}^{n} v_{i}^{K}}-\frac{1}{N} \sum_{i=1}^{n} \ln v_{i}\right]$

$A=\left(\frac{1}{N} \sum_{i=1}^{n} v_{i}^{K}\right)^{\frac{1}{K}}$

where $v_{i}$ is the non-zero speed of the wind at a time $i$ and $N$ the number of nonzero wind speed data. The average wind speed $V_{m}$ can be calculated according to Weibull parameters as follows [49-51]:

$V_{m}=A \cdot \Gamma\left(1+\frac{1}{K}\right)$

where $\Gamma$ is the gamma function

\subsection{Wind power density}

The power of the wind that flows at speed $\mathrm{v}$ through a blade sweep area $\mathrm{S}\left(\mathrm{m}^{2}\right)$ is the cubic of its velocity and is given by the following equation [52]:

$P(v)=\frac{1}{2} \cdot S \cdot \rho \cdot V_{m}^{3}$

where $\rho$ is the density of the air $\left(\mathrm{Kg} / \mathrm{m}^{3}\right)$. The wind power density of a site can be expressed using the Weibull parameters by the following relation:

$\frac{P}{S}=\frac{1}{2} \cdot \rho \cdot A^{3} \cdot \Gamma\left(1+\frac{3}{K}\right)$

\section{RESULTS AND DISCUSSION}

Figure 2 represents the annual Weibull distributions for both Bechar and Tindouf sites; according to the results obtained, we find that the wind speed covers an interval of up to $8 \mathrm{~m} / \mathrm{s}$ for the Bechar site and $10 \mathrm{~m} / \mathrm{s}$ for the Tindouf site. The scale factor values for Bechar and Tindouf are respectively $4.2533 \mathrm{~m} / \mathrm{s}$ and $5.7846 \mathrm{~m} / \mathrm{s}$. The shape of the two curves is determined by a shape parameter equal to 2.8529 for Bechar and 3.4964 for Tindouf.

The seasonal Weibull distribution at $10 \mathrm{~m}$ for the two sites studied is shown in Figure 3. It is shown that all curves have a similar trend of wind speeds for the Weibull distribution. There is no season in the two studied sites where the wind 
speed does not exceed $10 \mathrm{~m} / \mathrm{s}$ except for the spring of the Tindouf site where the speed interval extends up to $12 \mathrm{~m} / \mathrm{s}$.
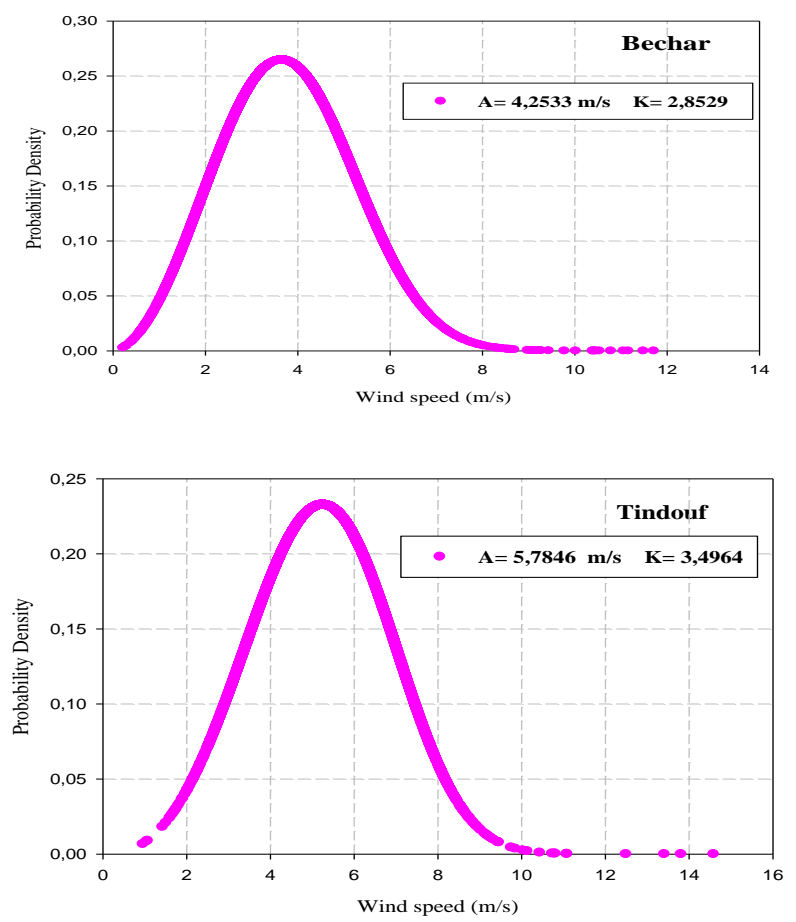

Figure 2. Annual Weibull wind distribution at $10 \mathrm{~m}$

Table 2. Annual average speed and power density at $10 \mathrm{~m}$

\begin{tabular}{ccc}
\hline & Bechar & Tindouf \\
\hline $\mathrm{V}(\mathrm{m} / \mathrm{s})$ & 3.8116 & 5.3980 \\
\hline $\mathrm{P}\left(\mathrm{W} / \mathrm{m}^{2}\right)$ & 33.9173 & 96.3376 \\
\hline
\end{tabular}

From Table 2, we note that the average annual speed does not exceed $5.4 \mathrm{~m} / \mathrm{s}$.
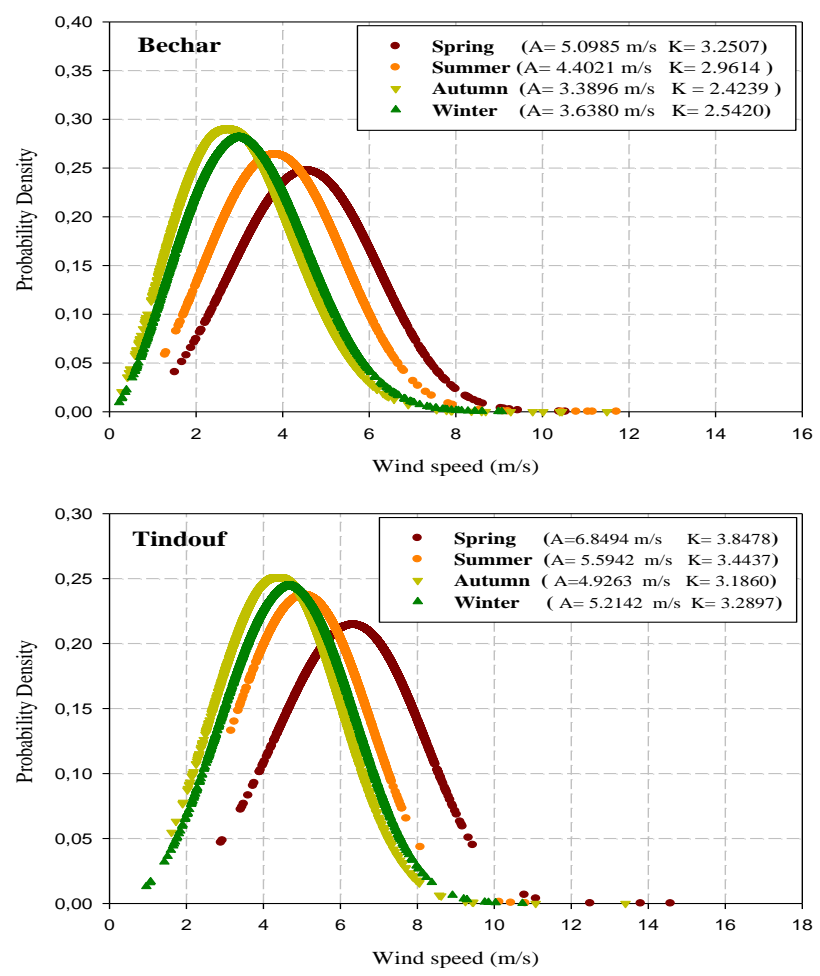

Figure 3. Seasonal Weibull wind distribution at $10 \mathrm{~m}$
Table 3. Seasonal average power speed and density at $10 \mathrm{~m}$

\begin{tabular}{ccccc}
\hline & Bechar & \multicolumn{3}{c}{ Tindouf } \\
\hline Season & $\mathrm{V}(\mathrm{m} / \mathrm{s})$ & $\mathrm{P}\left(\mathrm{W} / \mathrm{m}^{2}\right)$ & $\mathrm{V}(\mathrm{m} / \mathrm{s})$ & $\mathrm{P}\left(\mathrm{W} / \mathrm{m}^{2}\right)$ \\
\hline Spring & 4.8153 & 68.3868 & 6.6295 & 178.4226 \\
\hline Summer & 4.1230 & 42.9282 & 5.4584 & 99.6075 \\
\hline Autumn & 3.0512 & 17.3995 & 4.60 & 59.6172 \\
\hline Winter & 3.2166 & 20.3838 & 4.8575 & 70.2008
\end{tabular}

According to Table 3, we note that the minimum value of the average wind speed is in the autumn season for the two sites Bechar and Tindouf with $3.0512 \mathrm{~m} / \mathrm{s}$ and $4.60 \mathrm{~m} / \mathrm{s}$ respectively and the maximum value is in season spring with $4.8153 \mathrm{~m} / \mathrm{s}$ and $6.6295 \mathrm{~m} / \mathrm{s}$ respectively.
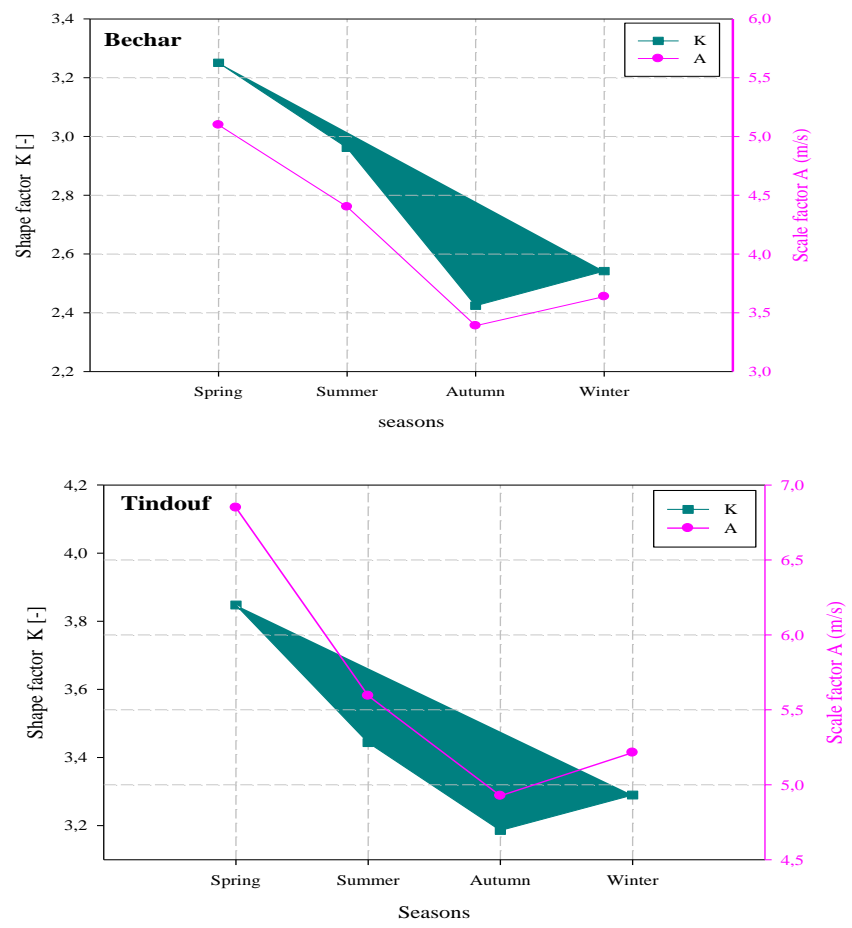

Figure 4. Seasonal Weibull distribution parameters at $10 \mathrm{~m}$

In addition, the value of the average power density varies between $17.39 \mathrm{~W} / \mathrm{m}^{2}$ and $68.38 \mathrm{~W} / \mathrm{m}^{2}$ for Bechar and between $59.61 \mathrm{~W} / \mathrm{m}^{2}$ and $178.42 \mathrm{~W} / \mathrm{m}^{2}$ for Tindouf.

Figure 4 represents the seasonal distribution of the two Weibull parameters during the study period. We note that the scale factor A reaches its maximum value in spring for Bechar and Tindouf with $5.0985 \mathrm{~m} / \mathrm{s}$ and $6.8494 \mathrm{~m} / \mathrm{s}$ respectively. In addition, its minimum value is in autumn for both Bechar and Tindouf sites with $3.3896 \mathrm{~m} / \mathrm{s}$ and 4.9263 $\mathrm{m} / \mathrm{s}$ respectively. We also note that the form factor $\mathrm{K}$ takes its maximum in spring with 3.8478 for Tindouf and 3.2507 for Bechar.

The monthly Weibull wind distribution study presented in Figure 5 and the monthly distribution of the two Weibull parameters presented in Figure 6 give an increase of the $\mathrm{K}$ shape parameter in the warm months from 2.8423 to 3.3410 for Bechar and between 3.4089 and 3.8941 for Tindouf. The minimum values are for cold months from 1.9109 to 2.6504 for Bechar and between 3.0484 and 3.3436 for Tindouf. The analysis also gives a maximum value of the A scale parameter in May for the two Bechar and Tindouf sites with respectively $5.3271 \mathrm{~m} / \mathrm{s}$ and $7.0083 \mathrm{~m} / \mathrm{s}$. 
Autumn \& Winter Months - Bechar

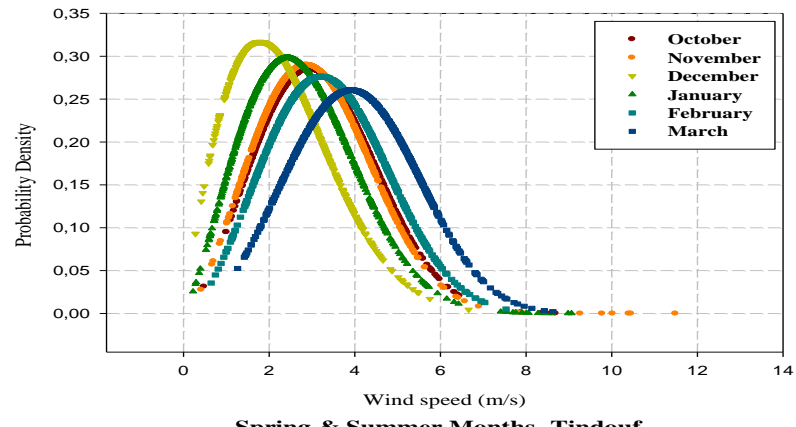

Spring \& Summer Months- Tindouf

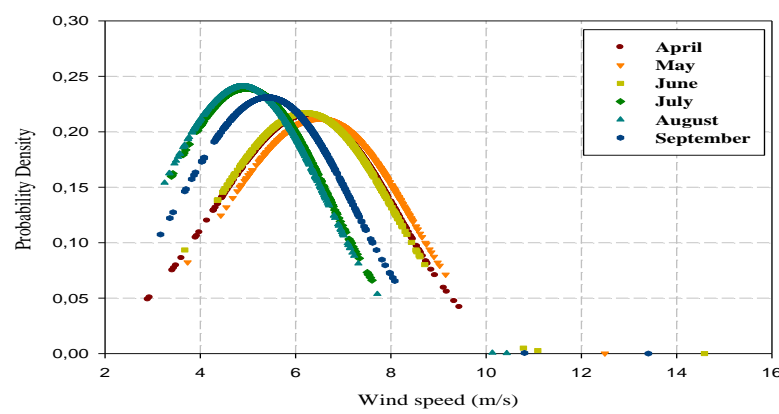

Autumn \&Winter Months - Tindouf

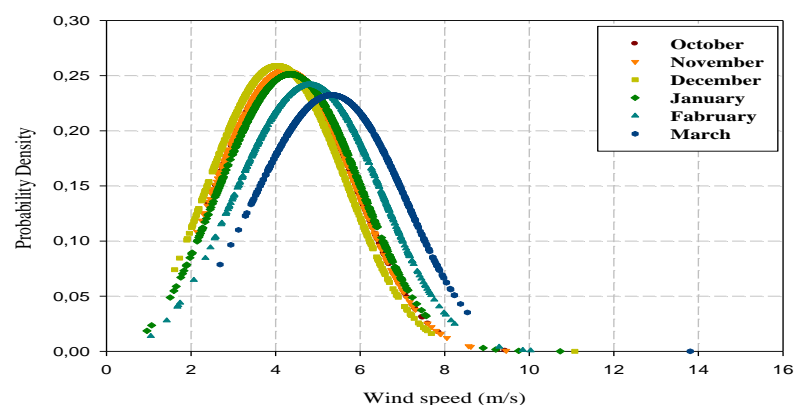

Figure 5. Monthly Weibull wind distribution at a height of $10 \mathrm{~m}$

The monthly variation of mean wind speed and the mean power density at $10 \mathrm{~m}$ above ground level is mentioned in the table 4 . For the Bechar site, we note that the minimum value of the mean speed is in December with $2.4538 \mathrm{~m} / \mathrm{s}$ and the maximum value is in May with $5.0555 \mathrm{~m} / \mathrm{s}$. In addition, the mean power density varies between $9.0492 \mathrm{~W} / \mathrm{m}^{2}$ in December and $79.1420 \mathrm{~W} / \mathrm{m}^{2}$ in May. For the Tindouf site, we observe that the monthly mean wind speed varies between $4.2501 \mathrm{~m} / \mathrm{s}$ in December and a maximum value of $6.8501 \mathrm{~m} / \mathrm{s}$ in May. Furthermore, the mean power density varies between $47.0230 \mathrm{~W} / \mathrm{m}^{2}$ and $196.8801 \mathrm{~W} / \mathrm{m}^{2}$.

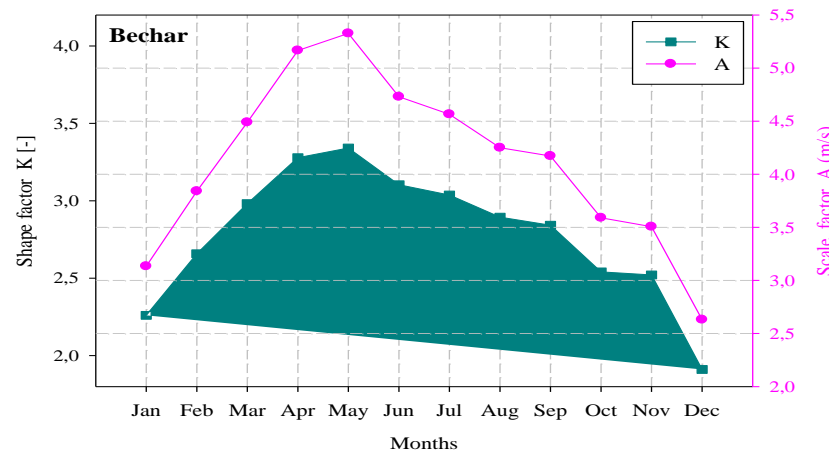

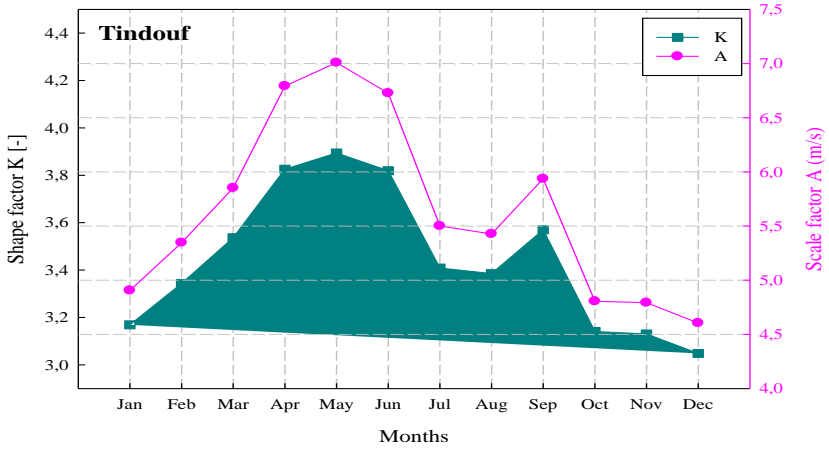

Figure 6. Monthly Weibull distribution parameters at 10

Table 4. Monthly variations of mean wind speed and power density at $10 \mathrm{~m}$

\begin{tabular}{ccccc}
\hline & \multicolumn{2}{c}{ Bechar } & \multicolumn{2}{c}{ Tindouf } \\
\hline Months & $\mathrm{V}(\mathrm{m} / \mathrm{s})$ & $\mathrm{P}\left(\mathrm{W} / \mathrm{m}^{2}\right)$ & $\mathrm{V}(\mathrm{m} / \mathrm{s})$ & $\mathrm{P}\left(\mathrm{W} / \mathrm{m}^{2}\right)$ \\
\hline January & 2.7395 & 12.5931 & 4.5445 & 57.4867 \\
\hline February & 3.4735 & 25.6688 & 5.0155 & 77.2790 \\
\hline March & 4.1080 & 42.4622 & 5.5397 & 104.1263 \\
\hline April & 4.8835 & 71.3363 & 6.5815 & 174.6145 \\
\hline May & 5.0555 & 79.1420 & 6.8501 & 196.8801 \\
\hline June & 4.4927 & 55.5446 & 6.5198 & 169.7526 \\
\hline July & 4.2641 & 47.4897 & 5.3744 & 95.0790 \\
\hline August & 4.0206 & 39.8080 & 5.2882 & 90.5774 \\
\hline September & 3.8973 & 36.2571 & 5.7682 & 117.5516 \\
\hline October & 3.2891 & 21.7945 & 4.5867 & 59.1039 \\
\hline November & 3.0735 & 17.7829 & 4.4910 & 55.4797 \\
\hline December & 2.4538 & 9.0492 & 4.2501 & 47.0230 \\
\hline
\end{tabular}

\section{CONCLUSION}

Through this study, the monthly, seasonal and annual Weibull parameters, mean wind speed and wind power densities are determined at a height of $10 \mathrm{~m}$ at two sites in the southwestern of Algeria, to provide information of wind resources. The results of this study can be concluded as follows:

The analysis gives a potential correlation between the mean temperature of the air and the factor of shape $\mathrm{K}$ in both sites where the biggest values are determined in the hot months. His minimal monthly value estimated at Becher equal to 1.9109 in December while the maximum is estimated at 3.8941 in May at Tindouf. The minimal seasonal value estimated at Becher equal to 2.4239 in autumn while the maximum equals to 3.8478 in Spring at Tindouf.

The seasonal analysis of the mean wind speed allowed us to show clearly that the spring remains the best beloved season. The maximal monthly value of the mean speed for both sites Bechar and Tindouf is in May with $5.0555 \mathrm{~m} / \mathrm{s}$ and $6.8501 \mathrm{~m} / \mathrm{s}$ respectively.

The spring supplies the highest mean wind power density on both sites Becher and Tindouf with $68.3868 \mathrm{w} / \mathrm{m}^{2}$ and $178.4226 \mathrm{w} / \mathrm{m}^{2}$ respectively.

The present study leads to estimate completely the wind potential in the region Sahara of Algeria and to request afterward a possible feasibility of a project of the wind farm. 


\section{REFERENCES}

[1] Yves Jannot, Thermique solaire, (2011). http://www.thermique55.com/principal/thermiquesolair e.pdf.

[2] Kost C, Pfluger B, Eichhammer W, Ragwitz M. (2011). Fruitful symbiosis: Why an export bundled with wind energy is the most feasible option for North African concentrated solar power. Energy Policy Asian Energy Security 39(11): 7136-7145. https://doi.org/10.1016/j.enpol.2011.08.032

[3] Komendantova N, Patt A, Barras L, Battaglini A. (2012). Perception of risks in renewable energy projects: The case of concentrated solar power in North Africa. Energy Policy Strategic Choices for Renewable Energy Investment 40:

103-109. https://doi.org/10.1016/j.enpol.2009.12.008

[4] Toufik H. (2006). Developpement des energies renouvelables en Algerie. National Conference on Renewable Energies and Sustainable Development. Laghouat, Algeria.

[5] Boudghene Stambouli A. (2011). Promotion of renewable energies in Algeria: Strategies and perspectives. Renewable and Sustainable Energy Reviews 15(2): 1169-1181 https://doi.org/10.1016/j.rser.2010.11.017

[6] Hamakawa Y. (2002). Recent progress in solar photovoltaic energy conversion. JSAP International 5: 30-35.

[7] Salvação N, Guedes Soares C. (2018). Wind resource assessment offshore the Atlantic Iberian coast with the WRF model. Energy 145: 276-287. https://doi.org/10.1016/j.energy.2017.12.101

[8] Li J, Wang XF, Yu X. (2018). Use of spatio-temporal calibrated wind shear model to improve accuracy of wind resource assessment. Applied Energy 213: 469485. https://doi.org/10.1016/j.apenergy.2018.01.063

[9] Jung C, Schindler D. (2018). 3d statistical mapping of Germany wind resource using WSWS. Energy Conversion and Management 159: 96-108 https://doi.org/10.1016/j.enconman.2017.12.095

[10] Ahmed Shata A. (2018). Wind resource assessment and economics of electric generation at four locations in Sinai Peninsula. Egypt. Journal of Cleaner Production 183: 1170-1183. https://doi.org/10.1016/j.jclepro.2018.02.182

[11] Mahdy M, Bahaj AS. (2018). Multi criteria decision analysis for offshore wind energy potential in Egypt. Renewable Energy 118: 278-289. https://doi.org/10.1016/j.renene.2017.11.021

[12] Ahmed Shata A. (2018). Wind energy characteristics and wind park installation in shark el-Ouinat. Egypt. Renewable and Sustainable Energy Reviews 82: 734 742. https://doi.org/10.1016/j.rser.2017.09.031

[13] Chancham C, Waewsak J, Gagnon Y. (2017). Offshore wind resource assessment and wind power plant optimization in the gulf of Thailand. Energy 139: 706731. https://doi.org/10.1016/j.energy.2017.08.026

[14] Amirinia G, Mafi S, Mazaheri S. (2017). Offshore wind resource assessment of Persian Gulf using uncertainty analysis and GIS. Renewable Energy 113: 915-929. https://doi.org/10.1016/j.renene.2017.06.070

[15] Khan KS, Tariq M. (2018). Wind resource assessment using sodar and meteorological mast a case study of
Pakistan. Renewable and Sustainable Energy Reviews 81: https://doi.org/10.1016/j.rser.2017.06.050

[16] Liu JK, Gao CY, Ren JZ, Gao ZQ, Liang HW, Wang LL. (2018). Wind resource potential assessment using a long term tower measurement approach: A case study of Beijing in china. Journal of Cleaner Production 174: 917-926. https://doi.org/10.1016/j.jclepro.2017.10.347

[17] Laudari R, Sapkota B, Banskota K. (2018). Validation of wind resource in 14 locations of Nepal. Renewable Energy, 119: 777-786. https://doi.org/10.1016/j.renene.2017.10.068

[18] Veronesi F, Grassi S, Raubal M. (2016). Statistical learning approach for wind resource assessment. Renewable and Sustainable Energy Reviews 56: 836850. https://doi.org/10.1016/j.rser.2015.11.099

[19] Solyali D, Altunç M, Tolun S, Aslan Z. (2016). Wind resource assessment of northern Cyprus. Renewable and Sustainable Energy Reviews 55: 180-187.

[20] Simões T, Estanqueiro A. (2016). A new methodology for urban wind resource assessment. Renewable Energy 89: https://doi.org/10.1016/j.renene.2015.12.008

[21] Oh KY, Kim JY, Lee JS, Ryu KW. (2012). Wind resource assessment around Korean peninsula for feasibility study on $100 \mathrm{MW}$ class offshore wind farm. Renewable Energy 42: 217-226. https://doi.org/10.1016/j.renene.2011.08.012

[22] Oh IKY, Kim JY, Lee JK, Ryu MS, Lee JS. (2012). An assessment of wind energy potential at the demonstration offshore wind farm in Korea. Energy and Exergy Modelling of Advance Energy Systems 46(1): 555-563. https://doi.org/10.1016/j.energy.2012.07.056

[23] Chellali F, Khellaf A, Belouchrani A, Recioui A. (2011). A contribution in the actualization of wind map of Algeria. Renewable and Sustainable Energy Reviews $15(2)$ : 993-1002. https://doi.org/10.1016/j.rser.2010.11.025

[24] Kasbadji Merzouk N. (2000). Wind energy potential of Algeria. Renewable Energy 21(3): 553-562. https://doi.org/10.1016/S0960-1481(00)00090-2

[25] Kasbadji Merzouk N. (2006). Evaluation du gisement energetique eolien. Contribution à la determination du profil vertical de la vitesse du vent en Algerie. PhD Thesis, These de doctorat. Universite Abou Bekr Belkaid, Tlemcen.

[26] Himri Y, Himri S, Boudghene Stambouli A. (2009). Assessing the wind energy potential projects in Algeria. Renewable and Sustainable Energy Reviews 13(8): 2187-2191. https://doi.org/10.1016/j.rser.2009.03.003

[27] Himri Y, Himri S, Boudghene Stambouli A. (2010). Wind power resource in the south-western region of Algeria. Renewable and Sustainable Energy Reviews 14(1): 554-556. https://doi.org/10.1016/j.rser.2009.07.018

[28] Himri Y, Rehman S, Draoui B, Himri S. (2008). Wind power potential assessment for three locations in Algeria. Renewable and Sustainable Energy Reviews 12(9): 2495-2504 https://doi.org/10.1016/j.rser.2007.06.007

[29] Himri Y, Rehman S, Agus Setiawan A, Himri S. (2012). Wind energy for rural areas of Algeria. Renewable and Sustainable Energy Reviews 16(5): 2381-2385. https://doi.org/10.1016/j.rser.2012.01.055 
[30] Himri Y, Boudghene Stambouli A, Draoui B. (2009). Prospects of wind farm development in Algeria. Desalination 239(1): 130-138. https://doi.org/10.1016/j.desal.2008.03.013

[31] Himri Y, Boudghene Stambouli A, Draoui B, Himri S. (2009). Review of wind energy use in Algeria. Renewable and Sustainable Energy Reviews 13(4): 910914. https://doi.org/10.1016/j.rser.2008.02.006

[32] Boudia SM, Guerri O. (2015). Investigation of wind power potential at Oran, northwest of Algeria. Energy Conversion and Management 105: 81-92. https://doi.org/10.1016/j.enconman.2015.07.055

[33] Boudia SM, Berrached S, Bouri S. (2016). On the use of wind energy at Tlemcen, north-western region of Algeria. Energy Procedia 93: 141-145. https://doi.org/10.1016/j.egypro.2016.07.162

[34] Boudia SM, Benmansour A, Tabet Hellal MA. (2014). Wind energy resource assessment at Tindouf region, extreme southwest of Algeria. In Engineering and Manufacturing Technologies of Applied Mechanics and Materials 541: 972-976 https://doi.org/10.4028/www.scientific.net/AMM.541542.972

[35] Boudia SM, Benmansour A, Ghellai N, Benmdjahed M, Tabet Hellal M.A. (2012). Temporal assessment of wind energy resource in Algerian highlands regions. Revue des Energies Renouvelables 15(03): 43-55.

[36] Boudia SM, Benmansour A, Ghellai N, Benmedjahed M, Tabet Hellal MA. (2012). Temporal wind energy resource assessment at Ghardaia region. SIENR'12 Ghardaïa. Revue des Energies Renouvelables, pp. 67-74.

[37] Boudia SM, Benmansour A, Ghellai N, Benmedjahed M, Tabet Hellal MA. (2012). Monthly and seasonal assessment of wind energy potential in Mechria region, occidental highlands of Algeria. International Journal of Green $\quad$ Energy 243 : 255 https://doi.org/10.1080/15435075.2011.621482

[38] Benmedjahed M, Bouzid Z, Ghellai N. (2015). Wind potential assessment of AIN salah in Algeria; calculation of the cost energy. International Journal of Energy and Power Engineering 4(2): 38-42.

[39] Benmedjahed M, Ghellai N, Benmansour A, Boudai SM, Tabet Hellal MA. (2014). Assessment of wind energy and energy cost in Algeria. International Journal of Renewable Energy 9(1): 31-40.

[40] Bouzid Z, Ghellai N, Belarbi M. (2014). Assessment of wind resource and production in Oran, Algeria. International Journal on Computational Sciences \& Applications (IJCSA) 4(5).

[41] Diaf S, Belhamel M, Haddadi M, Alain L, Al. (2007). Assessment of wind energy resource in southern Algeria. Revue des Energies Renouvelables 10(3): 321333.

[42] Aksas M, Gama A. (2011). Assessment of wind and solar energy resources in Batna, Algeria. Energy Procedia 6: 459-466. https://doi.org/10.1016/j.egypro.2011.05.053

[43] NCDC, National Climatic Data Center, [online] http://www.ncdc.noaa.gov
[44] BoroumandJazi G, Rismanchi B, Saidur R. (2013). Technical characteristic analysis of wind energy conversion systems for sustainable development. Energy Conversion and Management 69: 87-94. https://doi.org/10.1016/j.enconman.2013.01.030

[45] Ahmed Shata A. (2010). Wind energy as a potential generation source at Ras Benas, Egypt. Renewable and Sustainable Energy Reviews 14(8): 2167-2173. https://doi.org/10.1016/j.rser.2010.03.006

[46] Carla Freitas de Andrade and Hely Falcão Maia Neto and Paulo Alexandre Costa Rocha and Maria Eugênia Vieira da Silva. (2014). An efficiency comparison of numerical methods for determining weibull parameters for wind energy applications: A new approach applied to the northeast region of brazil. Energy Conversion and Management 86: 801-808. https://doi.org/10.1016/j.enconman.2014.06.046

[47] Maatallah T, El Alimi S, Dahmouni AW, Nasrallah SB. (2013). Wind power assessment and evaluation of electricity generation in the gulf of Tunis, Tunisia. Sustainable Cities and Society 6: 1-10. https://doi.org/10.1016/j.scs.2012.06.004

[48] Seguro JV, Lambert TW. (2000). Modern estimation of the parameters of the Weibull wind speed distribution for wind energy analysis. Journal of Wind Engineering and Industrial Aerodynamics 85(1): 75-84. https://doi.org/10.1016/S0167-6105(99)00122-1

[49] Jamil M, Parsa S, Majidi M. (1995). Wind power statistics and an evaluation of wind energy density. Renewable Energy 6(5): 623-628. https://doi.org/10.1016/0960-1481(95)00041-H

[50] Kavak Akpinar E, Akpinar S. (2005). An assessment on seasonal analysis of wind energy characteristics and wind turbine characteristics. Energy Conversion and Management $46(11)$ : 1848-1867. https://doi.org/10.1016/j.enconman.2004.08.012

[51] Paulo Alexandre Costa Rocha and Ricardo Coelho de Sousa and Carla Freitas de Andrade and Maria Eugênia Vieira da Silva. (2012). Comparison of seven numerical methods for determining Weibull parameters for wind energy generation in the northeast region of Brazil. Applied Energy 89(1): 395-400. https://doi.org/10.1016/j.apenergy.2011.08.003

[52] Li M, Li XG. (2005). Mep-type distribution function: a better alternative to Weibull function for wind speed distributions. Renewable Energy 30(8): 1221-1240.

\section{NOMENCLATURE}

$A$

$K$

$P$

V

The parameter of scale of Weibull, $\mathrm{m} / \mathrm{s}$ The parameter of shape of Weibull The power of the wind, $\mathrm{W} / \mathrm{m}^{2}$ The wind speed, $\mathrm{m} / \mathrm{s}$.

\section{Greek symbols}

$\Gamma$

The gamma function

The density of the air, $\mathrm{Kg} / \mathrm{m}^{3}$ 